\title{
Development of Value Added Product from Dehydrated Betel Leaves Powder
}

\author{
Akshata A. Vernekar ${ }^{1^{*}}$, K.G. Vijayalaxmi ${ }^{1}$ and V.C. Suvarna ${ }^{2}$ \\ ${ }^{1}$ Department of Food Science and Nutrition, ${ }^{2}$ Department of Agricultural Microbiology, \\ University of Agricultural Sciences, GKVK, Bangalore-560065, Karnataka, India \\ *Corresponding author
}

\section{A B S T R A C T}

Keywords

Dehydration, Betel leaves, Nutritional, Khakhra, Sensory score and shelf life

Article Info

Accepted:

06 August 2018

Available Online:

10 September 2018
The present study was undertaken to determine the sensory quality and nutrient content of khakhra prepared with the incorporation of betel leaves powder both Kariyele and Ambadiyele at 5, 7.5 and 10\% level. Khakhra were prepared by using wheat flour as base ingredient along with betel leaves powder. The developed khakhra were evaluated organoleptically using nine point scale. Khakhra prepared with $5 \%$ of Kariyele and Ambadiyele powder was best acceptable and used for their nutrient computation. Results revealed that khakhra prepared with Kariyele powder was found to be high in moisture $(12.76 \%)$, protein $(12.87 \mathrm{~g})$ and vitamin-C (2.79mg) whereas Ambadiyele khakhra was found to be high in ash $(2.23 \mathrm{~g})$, crude fiber $(2.97 \mathrm{~g})$, carbohydrate $(69.66 \mathrm{~g}), \beta$ - carotene $(378.68 \mu \mathrm{g})$, calcium $(215.85 \mathrm{mg})$ and iron $(7.30 \mathrm{mg})$. Shelf life study based on sensory evaluation, microbial load and moisture content revealed that both khakhras were acceptable upto 60days of storage under ambient temperature.

\section{Introduction}

India's diverse climate ensures availability of all varieties of fresh fruits and vegetables. India ranks second in fruits and vegetables production in the world, next to China. In India more than 40 kinds of vegetables belonging to different groups, like Solanaceous, Cucurbitaceous, Leguminous, Cruciferous, root crops and leafy vegetables are grown in tropical, subtropical and temperate regions. As per National Horticulture Database published by National Horticulture Board of India, during 2012-13
India produced 162.19 million metric tonnes of vegetables with cultivated area of 9.21 million hectares. The leafy vegetables are highly perishable in nature and have very short shelf life. Green leafy vegetables (GLV) represent an excellent component of the habitual diet in the tropical and temperate countries. Vegetables are important protective foods and highly beneficial for the maintenance of health and prevention of disease. Green leafy vegetables occupy an important place among the food crops as these provide adequate amounts of many vitamins and minerals (Kakade and Neeha, 2014). 
The fresh leaves of betel vine are popularly known as Paan in India the scientific name of betel vine is Piper betelL. It belongs to the family Piperaceae, The vine is a dioecious (male and female plants are different), shade loving perennial root climber. There are about 100 varieties of betel vine in the world, of which about 40 are found in India and 30 in West Bengal and the origin of betel vine is Malaysia. Betel leaves are consumed by about 15-20 million people in the country. It is cultivated following the traditional methods in India on about 55,000 ha with an annual production worth about Rs 9000 million. (Guha, 2006). Leaves are rich source of many antioxidants viz. flavonoids, terpenoids, tannins, alkaloids, saponins etc. Piper betel helps in curing various diseases like hypertension, diabetes, brain toxin, boils and abscesses, headache, leucorrhoea, cuts and injuries, ringworm infestation, swelling of gum, voice problems, rheumatism, wound healing, obesity, conjunctivitis, constipation, abrasion etc. (Aishwarya et al., 2016).

Betel vine is one of the invaluable medicinal plants, leaves are used for many medicinal purposes and has been described from ancient time as an aromatic stimulo-carminative, astringent and aphrodisiac (Sripradha, 2014) Despite of high nutritional value they are not utilized to the extent they should be, because they are highly seasonal, perishable and have short shelf life. Among various methods of preservation, dehydration is one of the most popular and method. Dehydration increases the storage period of GLV and make them available throughout the year even in offseason, thus, supplies the important nutrients in a concentrated form. Dehydrated foods are more concentrated source of minerals than any other preserved form of food stuff (Singh et al., 2007). Betel leaves can be easily dehydrated and added in various food products in order to increase their nutritive value. Therefore, the present study was undertaken to develop Khakhra from dehydrated both Kariyele and Ambadiyele betel leaves.

\section{Materials and Methods}

The two varieties of betel leaves i.e. Kariyele and Ambadiyele required for research work were procured from the local market of Bengaluru. The damaged, discoloured leaves were manually separated and fresh, green leaves were selected, washed in tap water to remove extraneous matter. Leaves were finely chopped, weighed and then they were dried in hot air oven at $60^{\circ} \mathrm{C}$ for 3 hours. The dehydrated leaves were powdered and were subjected to nutrient analysis. Moisture, protein, fat, crude fiber, ash, carbohydrate, energy, potassium, sodium, iron and zinc were estimated using standard methods(AOAC,1980).Calcium content was determined by titration method described by (Heau et al., 1965). $\beta$-carotene by spectrophotometer method (Ranganna, 2002), vitamin-C by titration method using iodate solution (Tauber and Kleiner, 1935), antioxidant activity by DPPH (2, 2-diphenyl1-picrylhydrazyl) radical scavenging activity method (Kang and Saltveit, 2002) and Phosphorus by atomic spectrophotometer (Adelowo et al., 2016). Khakhra was prepared by incorporating dehydrated betel leaves powder both Kariyele and Ambadiyele. Nutrient composition of the best accepted Khakhra was computed based on the nutritional composition of the ingredients (Gopalan et al., 2014). Storage study was done for the khakhra based on sensory evaluation, moisture content and microbial load.

\section{Results and Discussion}

\section{Nutritional analysis of dehydrated betel leaves powder}

The findings of nutritional analysis of dehydrated betel leaves powder is presented in 
Table 1. It was found that dehydrated Kariyele powder had 13.53 percent moisture, $13.47 \mathrm{~g}$ protein, $4.46 \mathrm{~g}$ fat, $14.66 \mathrm{~g}$ total ash, $5.2 \mathrm{~g}$ crude fiber, $48.63 \mathrm{~g}$ carbohydrate and $288.54 \mathrm{Kcal}$ energy. $\beta$-carotene $5440 \mu \mathrm{g}$, vitamin $\mathrm{C} 34.73 \mathrm{mg}$ and antioxidant content $43.01 \mathrm{mg}$ respectively. Minerals i.e. calcium, potassium, sodium, phosphorus, iron and zinc contents were 2018.8mg,4054 mg, $32.83 \mathrm{mg}, 213$, 23.15mg and $4.65 \mathrm{mg}$ respectively. Whereas Dehydrated Ambadiyele powder had 12.66 percent moisture, $12.07 \mathrm{~g}$ protein and $4.62 \mathrm{~g}$ fat. Amount of total ash was $15.33 \mathrm{~g}$, crude fibre $6.5 \mathrm{~g}$, carbohydrate48.82 g and energy 285.14 Kcal. $\beta$-carotene, vitamin $\mathrm{C}$ and antioxidant contents were $6693 \mu \mathrm{g}, 32.86 \mathrm{mg}$ and $39.81 \mathrm{mg}$ respectively and calcium $2894.2 \mathrm{mg}$, potassium $3822.3 \mathrm{mg}$, sodium $24.3 \mathrm{mg}$, phosphorus $242.3 \mathrm{mg}$, iron $40.98 \mathrm{mg}$ and zinc $6.75 \mathrm{mg}$. Moisture, protein, energy, vitamin$\mathrm{C}$, potassium and sodium were higher in Kariyele powder. The results were in accordance with Chauhan and Aishwarya (2016), who reported the nutrient content of dried betel leaves powder moisture $9.45 \%$, protein $3.30 \%$, fat $1.10 \%$, fiber $10.15 \%$, ash $6.87 \%$, carbohydrate $63.92 \%$, vitamin C, iron and calcium as $1.11 \%, 2.57 \%$ and $1.53 \%$ respectively on fresh weight basis. These values are lower than present study values except for fiber and carbohydrate, which might be due to difference in variety, drying condition and climatic conditions.

\section{Development of Khakhra}

Khakhra was prepared from both Kariyele and Ambadiyele. Table 2 shows the formulation of the developed Khakhra using dehydrated betel leaves powder. Sensory evaluation was done to check acceptance of the products using nine point hedonic scale by 21 semi-trained panel members.

Khakhra is also referred as crispy chapatti or roti. It is a common Gujarati Indian bread or snack item served during breakfast or snack time. It is simple to prepare and is made from whole wheat flour adding other ingredients and spices. It is also light weight and easily stored and packed (Verma and Bhatnagar, 2017). Three variations of khakhras were prepared by incorporating Kariyele powder and Ambadiyele powder at different levels i.e. 5, 7.5 and 10 per cent. Both Kariyele khakhra (BKK 1) and Ambadiyele khakhra (BAK1) was found to be best accepted at 5 percent incorporation with scores for appearance 8.23 and 8.19 , colour 8.04 and 7.95 , texture 8.09 and 8.42 , aroma 8.38 and 8.33 , taste 8.19 and 8.04 and overall acceptability 8.14 and 8.38 respectively. And control had scores for appearance, colour, texture, aroma, taste and overall acceptability as $8.47,8.33,8.23,8.23$, 8.14 and 8.19 respectively. The mean sensory scores of best accepted khakhra are given in Figure 1.

\section{Nutrient composition of best accepted Khakhras}

Nutrient composition of best accepted products and control were computed and presented in Table 4. It was found that Kariyele khakhra (BKK 1) was rich in moisture 12.76 per cent, protein 12.87, vitamin- C $12.79 \mathrm{mg}$. Whereas Ambadiyele khakhra (BAK1) had higher ash $2.23 \mathrm{~g}$, crude fiber $2.97 \mathrm{~g}, \beta$ - carotene $378.68 \mu \mathrm{g}$, calcium $215.85 \mathrm{mg}$ and iron $7.30 \mathrm{mg}$. Both Kariyele and Ambadiyele khakhra had $12.29 \mathrm{~g}$ fat content. Compared to betel leaves khakhra control had higher carbohydrate 70.69 and energy 444.78 Kcal because in betel leaves khakhra $5 \mathrm{~g}$ of wheat flour was replaced with 5 per cent betel leaves powder.

\section{Shelf life study of the developed products}

Best accepted Kariyele (BKK1) and Ambadiyele (BAK1) Khakhras along with control were packed in aluminium pouches 
and stored at room temperature. The samples were subjected for sensory evaluation, moisture content and microbial load on initial, $15^{\text {th }}, 30^{\text {th }}, 45^{\text {th }}$ and $60^{\text {th }}$ day.

Table 3 depicts mean sensory scores of betel leaves khakhra from initial day to end of storage period i.e. $60^{\text {th }}$ day. Results revealed that there was decrease in the sensory scores during storage period. The decrease in appearance score was from 8.47 to 7.71 , colour from 8.33 to 7.66 , texture from 8.23 to 7.71 , aroma from 8.23 to 7.57 , taste from 8.14 to 7.61 and overall acceptability was from 8.19 to 7.57 in control. Whereas BKK1 and BAK1 showed decrease of 8.23 to 7.52 and 8.19 to 7.52 respectively for appearance, 8.04 to 7.38 and 7.95 to 7.28 for colour, 8.09 to
7.42 and 8.42 to 7.57 for texture, 8.38 to 7.52 and 8.33 to 7.52 for aroma, 8.19 to 7.47 and 8.04 to 7.57 for taste and 8.14 to 7.66 and 8.38 to 7.76 for overall acceptability respectively. All three types of khakhras were acceptable even after 60 days of storage period. Scores for all sensory parameters decreased with increasing number of days of storage and this might be due to change in flavour and reduced crispiness of the khakhras. However khakhras were acceptable till 60 days. The results are in line with the study conducted by Punia and Gupta (2009) who reported that the sensory scores of the products i.e. soya ladoo, paushtikladoo, sev and mathi slightly decreased and free fatty acids, peroxide value and total sugar increased with the increase in storage period.

Fig.1 Mean sensory scores for best accepted khakhra

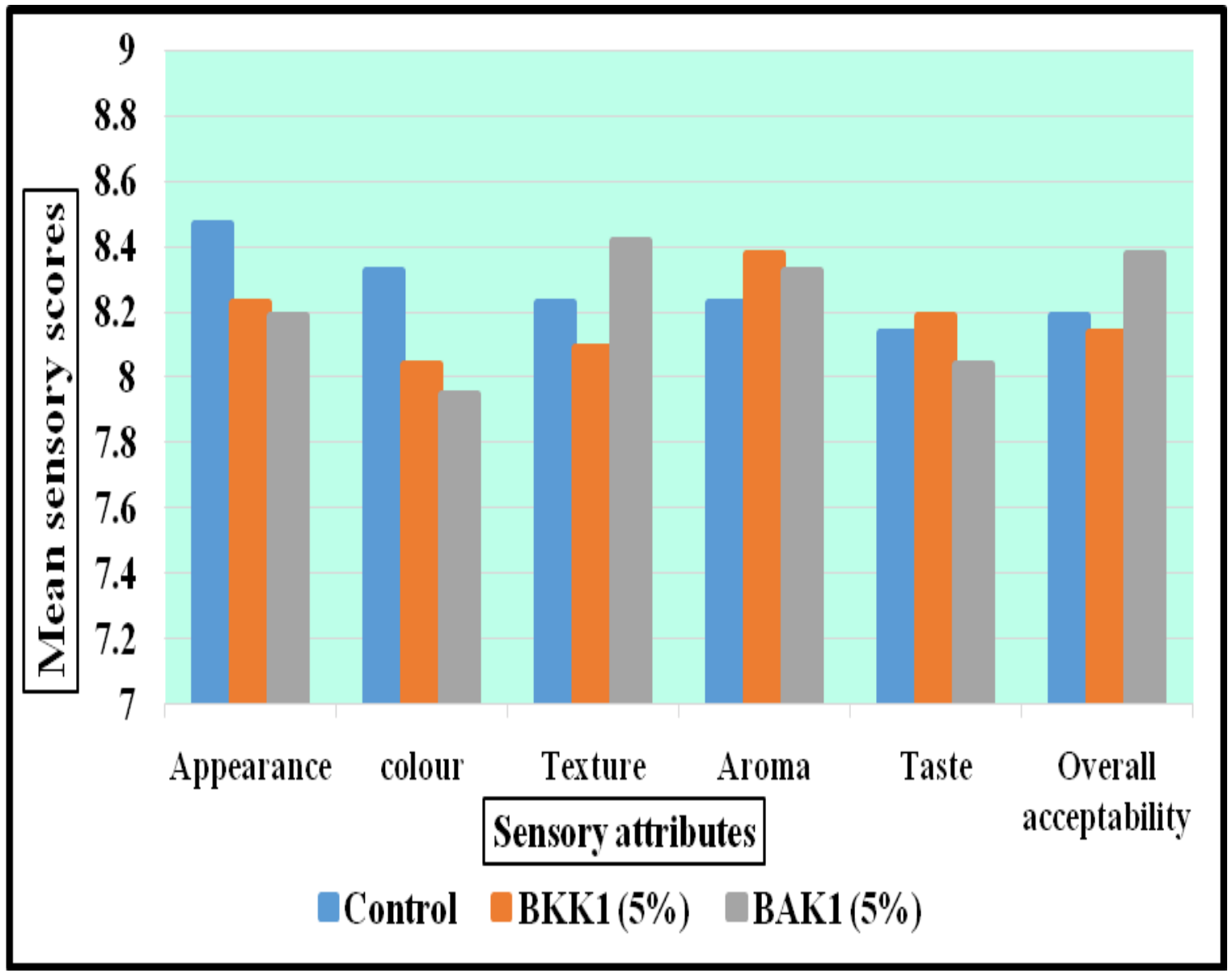


Fig.2 Mean moisture content of khakhra during storage

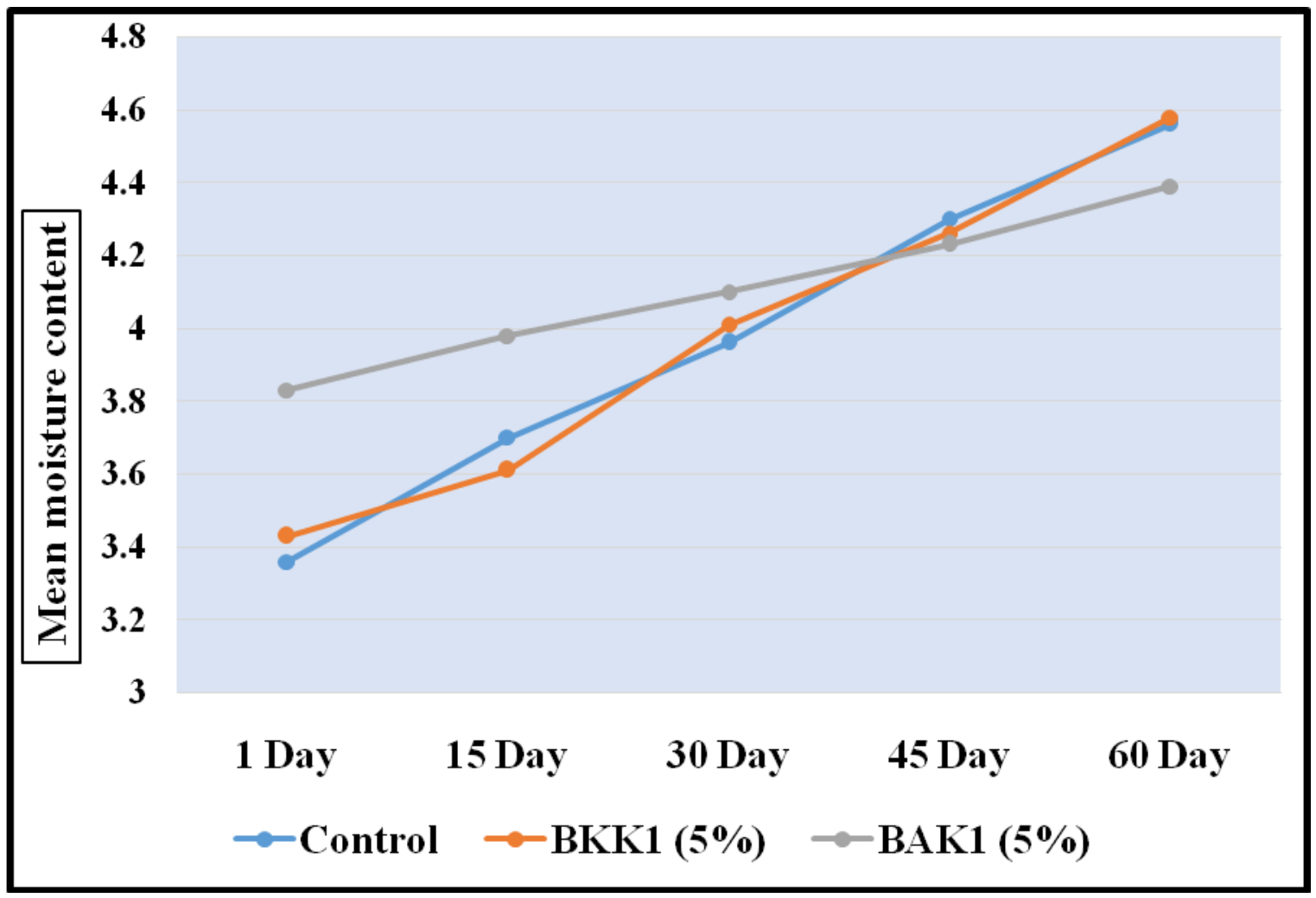

Table.1 Nutritional composition of dehydrated betel leaves powder (Per 100g dry weight)

\begin{tabular}{|c|c|c|}
\hline Nutrients & Kariyele & Ambadiyele \\
\hline Moisture (\%) & 13.53 & 12.66 \\
\hline Protein $(g)$ & 13.47 & 12.07 \\
\hline Fat (g) & 4.46 & 4.62 \\
\hline Total ash (g) & 14.66 & 15.33 \\
\hline Crude fiber (g) & 5.2 & 6.5 \\
\hline Carbohydrate (g) & 48.63 & 48.82 \\
\hline Energy (Kcal) & 288.54 & 285.14 \\
\hline \multicolumn{3}{|c|}{ Vitamins } \\
\hline$\beta$ - carotene $(\mu \mathrm{g})$ & 5440 & 6693 \\
\hline Vitamin C (mg) & 34.73 & 32.86 \\
\hline \multicolumn{3}{|c|}{ Minerals } \\
\hline Calcium (mg) & 2018.8 & 2894.2 \\
\hline Potassium (mg) & 4054 & 3822 \\
\hline Sodium (mg) & 32.83 & 24.3 \\
\hline Phosphorus (mg) & 213 & 242.3 \\
\hline Iron (mg) & 23.15 & 40.98 \\
\hline Zinc (mg) & 4.65 & 6.75 \\
\hline
\end{tabular}


Table.2 Development of betel leaves khakhra

\begin{tabular}{|l|c|c|}
\hline \multirow{2}{*}{\multicolumn{1}{|c|}{ Ingredients }} & \multicolumn{2}{c|}{ Quantity (g) } \\
\hline Wheat flour & CONTROL & I \\
\hline Cumin seeds & $\mathbf{1 0 0}$ & $\mathbf{9 5}$ \\
\hline Cumin powder & $\mathbf{1}$ & $\mathbf{1}$ \\
\hline Chilli powder & $\mathbf{1}$ & $\mathbf{1}$ \\
\hline Turmeric powder & $\mathbf{2}$ & $\mathbf{2}$ \\
\hline Salt & $\mathbf{0 . 5}$ & $\mathbf{0 . 5}$ \\
\hline Oil & $\mathbf{2}$ & $\mathbf{2}$ \\
\hline Betel leaves dehydrated powder & $\mathbf{1 0}$ & $\mathbf{1 0}$ \\
\hline
\end{tabular}

I - Betel leaves (Kariyele and Ambadiyele) powder at 5\% level

Table.3 Mean sensory score of betel leaves khakhra during shelf life study

\begin{tabular}{|c|c|c|c|c|c|c|c|}
\hline Products & Duration & Appearance & Colour & Texture & Aroma & Taste & $\begin{array}{c}\text { Overall } \\
\text { Acceptability }\end{array}$ \\
\hline \multirow{8}{*}{ Control } & Initial & 8.47 & 8.33 & 8.23 & 8.23 & 8.14 & 8.19 \\
\hline & $15^{\text {th }}$ day & 8.33 & 8.28 & 8.19 & 8.09 & 8.04 & 8.14 \\
\hline & $30^{\text {th }}$ day & 8.14 & 8.04 & 7.90 & 7.95 & 7.85 & 7.80 \\
\hline & $45^{\text {th }}$ day & 7.95 & 7.80 & 7.85 & 7.76 & 7.71 & 7.66 \\
\hline & $60^{\text {th }}$ day & 7.71 & 7.66 & 7.71 & 7.57 & 7.61 & 7.57 \\
\hline & $\mathrm{F}$ value & $*$ & $*$ & NS & $*$ & $*$ & $*$ \\
\hline & SEm \pm & 0.11 & 0.13 & 0.14 & 0.10 & 0.13 & 0.12 \\
\hline & $\mathrm{CD}$ at $5 \%$ & 0.33 & 0.36 & - & 0.29 & 0.38 & 0.35 \\
\hline \multirow{8}{*}{$\begin{array}{c}\text { BKK1 } \\
(5 \%)\end{array}$} & Initial & 8.23 & 8.04 & 8.09 & 8.38 & 8.19 & 8.14 \\
\hline & $15^{\text {th }}$ day & 8.14 & 7.95 & 7.95 & 8.23 & 8.00 & 8.04 \\
\hline & $30^{\text {th }}$ day & 7.95 & 7.80 & 7.76 & 7.90 & 7.85 & 7.90 \\
\hline & $45^{\text {th }}$ day & 7.76 & 7.61 & 7.57 & 7.71 & 7.66 & 7.76 \\
\hline & $60^{\text {th }}$ day & 7.52 & 7.38 & 7.42 & 7.52 & 7.47 & 7.66 \\
\hline & F value & $*$ & $*$ & $*$ & $*$ & $*$ & $*$ \\
\hline & SEm \pm & 0.12 & 0.14 & 0.12 & 0.11 & 0.13 & 0.10 \\
\hline & $\mathrm{CD}$ at $5 \%$ & 0.34 & 0.41 & 0.35 & 0.32 & 0.36 & 0.29 \\
\hline \multirow{8}{*}{$\begin{array}{c}\text { BAK1 } \\
(\mathbf{5 \%})\end{array}$} & Initial & 8.19 & 7.95 & 8.42 & 8.33 & 8.04 & 8.38 \\
\hline & $15^{\text {th }}$ day & 8.14 & 7.85 & 8.28 & 8.09 & 7.95 & 8.23 \\
\hline & $30^{\text {th }}$ day & 7.95 & 7.66 & 8.09 & 7.85 & 7.76 & 8.09 \\
\hline & $45^{\text {th }}$ day & 7.71 & 7.47 & 7.76 & 7.61 & 7.71 & 7.85 \\
\hline & $60^{\text {th }}$ day & 7.52 & 7.28 & 7.57 & 7.52 & 7.57 & 7.76 \\
\hline & F value & $*$ & $*$ & $*$ & $*$ & $*$ & $*$ \\
\hline & SEm \pm & 0.15 & 0.11 & 0.14 & 0.12 & 0.11 & 0.13 \\
\hline & $\mathrm{CD}$ at $5 \%$ & 0.42 & 0.33 & 0.40 & 0.35 & 0.33 & 0.38 \\
\hline
\end{tabular}

*- Significant at 5\% level, NS - Non significant, BKK1 - Betel leaves Kariyele khakhra 1 BAK1 - Betel leaves Ambadiyele khakhra 1 
Table.4 Nutrient composition of best accepted products

\begin{tabular}{|c|c|c|c|}
\hline \multirow{2}{*}{ Nutrients } & \multicolumn{3}{|c|}{ Khakhra } \\
\cline { 2 - 4 } & Control & BKK1 & BAK1 \\
\hline Moisture & 12.70 & 12.76 & 12.72 \\
\hline Protein (g) & 12.81 & 12.87 & 12.83 \\
\hline Fat (g) & 12.15 & 12.29 & 12.29 \\
\hline Ash(g) & 1.54 & 2.20 & 2.23 \\
\hline Crude filber (g) & 2.75 & 2.91 & 2.97 \\
\hline Carbohydrate & 70.69 & 69.65 & 69.66 \\
\hline Energy (K cal) & 444.78 & 442.17 & 441.98 \\
\hline B-carotene & 44.22 & 321.08 & 378.68 \\
\hline Vitamin C & 1.06 & 2.79 & 2.70 \\
\hline Calcium (mg) & 73.55 & 172.05 & 215.85 \\
\hline Iron (mg) & 5.519 & 6.42 & 7.30 \\
\hline
\end{tabular}

BKK1 - Betel leaves Kariyele khakhra 1(5\%), BAK1 - Betel leaves Ambadiyele khakhra 1 (5\%)

BKK1 - Betel leaves Kariyele khakhra 1 BAK1 - Betel leaves Ambadiyele khakhra 1

Table.5 Microbial population of betel leaves khakhra at different intervals

\begin{tabular}{|c|c|c|c|c|c|c|c|}
\hline & & \multicolumn{6}{|c|}{ Duration } \\
\hline \multirow{9}{*}{$\begin{array}{l}\text { Bacteria } \\
\left(\times 10^{2}\right. \\
\text { CFU/g) }\end{array}$} & & 0 & $15^{\text {th }}$ day & $30^{\text {th }}$ day & $45^{\text {th }}$ day & $60^{\text {th }}$ day & Mean \\
\hline & Control & 0.00 & 0.63 & 2.10 & 4.80 & 8.00 & 31.26 \\
\hline & BKK1 & 0.00 & 0.33 & 1.50 & 3.56 & 7.40 & 25.73 \\
\hline & BAK1 & 0.00 & 0.46 & 1.86 & 3.86 & 7.6 & 27.66 \\
\hline & Mean & 0.00 & 4.77 & 18.44 & 40.88 & 77.00 & \\
\hline & & \multicolumn{2}{|c|}{ F - Value } & \multicolumn{2}{|c|}{$\mathrm{SEm} \pm$} & \multicolumn{2}{|c|}{ CD@ $@ 5 \%$} \\
\hline & Treatments & \multicolumn{2}{|c|}{$*$} & \multicolumn{2}{|c|}{0.57} & \multicolumn{2}{|c|}{1.65} \\
\hline & Duration & \multicolumn{2}{|c|}{$*$} & \multicolumn{2}{|c|}{0.73} & \multicolumn{2}{|c|}{2.13} \\
\hline & $\mathrm{T} \times \mathrm{D}$ & \multicolumn{2}{|c|}{$*$} & \multicolumn{2}{|c|}{1.27} & \multicolumn{2}{|c|}{3.70} \\
\hline \multirow{9}{*}{$\begin{array}{l}\text { Moulds } \\
\left(\times 10^{2}\right. \\
\text { CFU/g })\end{array}$} & & 0 & $15^{\text {th }}$ day & $30^{\text {th }}$ day & $45^{\text {th }}$ day & $60^{\text {th }}$ day & Mean \\
\hline & Control & 0.00 & 0.16 & 0.30 & 0.73 & 1.06 & 4.46 \\
\hline & BKK1 & 0.00 & 0.06 & 0.20 & 0.53 & 0.90 & 3.40 \\
\hline & BAK1 & 0.00 & 0.06 & 0.26 & 0.56 & 0.96 & 3.73 \\
\hline & Mean & 0.00 & 0.88 & 2.55 & 6.11 & 9.77 & \\
\hline & & \multicolumn{2}{|c|}{$\mathrm{F}-$ Value } & \multicolumn{2}{|c|}{ SEm \pm} & \multicolumn{2}{|c|}{ CD@5\% } \\
\hline & Treatments & \multicolumn{2}{|c|}{ NS } & \multicolumn{2}{|c|}{0.40} & \multicolumn{2}{|c|}{-} \\
\hline & Duration & \multicolumn{2}{|c|}{$*$} & \multicolumn{2}{|c|}{0.52} & \multicolumn{2}{|c|}{1.51} \\
\hline & $\mathrm{T} \times \mathrm{D}$ & \multicolumn{2}{|c|}{ NS } & \multicolumn{2}{|c|}{0.90} & \multicolumn{2}{|c|}{-} \\
\hline \multirow{9}{*}{$\begin{array}{l}\text { Coliforms } \\
\left(\times 10^{2}\right. \\
\text { CFU/g })\end{array}$} & & 0 & $15^{\text {th }}$ day & $30^{\text {th }}$ day & $45^{\text {th }}$ day & $60^{\text {th }}$ day & Mean \\
\hline & Control & 0.00 & 0.00 & 0.16 & 0.36 & 0.50 & 2.00 \\
\hline & BKK1 & 0.00 & 0.00 & 0.06 & 0.20 & 0.30 & 1.20 \\
\hline & BAK1 & 0.00 & 0.00 & 0.10 & 0.30 & 0.40 & 1.66 \\
\hline & Mean & 0.00 & 0.00 & 1.33 & 2.77 & 4.00 & \\
\hline & & \multicolumn{2}{|c|}{$\mathrm{F}-$ Value } & \multicolumn{2}{|c|}{ SEm \pm} & \multicolumn{2}{|c|}{ CD@5\% } \\
\hline & Treatments & & & & & & \\
\hline & Duration & & & & & & \\
\hline & $\mathrm{T} \times \mathrm{D}$ & & & & & & \\
\hline
\end{tabular}

*Significant $(\mathrm{p} \leq 0.05)$, NS - Non significant, BKK1- Betel leaves Kariyele khakhra, BAK1- Betel leaves Ambadiyele khakhra 
Table.6 Mean moisture content of betel leaves khakhra during shelf life study

\begin{tabular}{|c|c|c|c|}
\hline \multirow{2}{*}{ Duration } & \multicolumn{3}{|c|}{ Moisture content } \\
\hline Initial & Control & BKK1 & BAK1 \\
\hline $\mathbf{1 5}^{\text {th }}$ day & 3.36 & 3.43 & 3.83 \\
\hline $\mathbf{1 3 0}^{\text {th }}$ day & 3.70 & 3.61 & 3.98 \\
\hline $\mathbf{4 5}^{\text {hl }}$ day & 3.96 & 4.01 & 4.10 \\
\hline $\mathbf{6 0}^{\text {th }}$ day & 4.30 & 4.26 & 4.23 \\
\hline F value & 4.56 & 4.58 & 4.39 \\
\hline SEm \pm & $*$ & $*$ & $*$ \\
\hline CD at 5\% & 0.06 & 0.05 & 0.07 \\
\hline
\end{tabular}

*- Significant at 5\% level, NS - Non significant, BKK1 - Betel leaves Kariyele khakhra 1, BAK1 - Betel leaves Ambadiyele khakhra 1

Results of microbial population estimated for total bacteria, moulds and coliforms by standard plate count method are presented in Table 5. The data related to bacterial population showed increasing trend in all variations throughout the storage period, but increase in betel leaves incorporated khakhra were lower compared to control. Results indicate that significant differences exist among all the variations at all stages of storage period for bacterial population. BKK1 treatment had significant low population of bacteria, leading to conclusion that BKK1 has more antibacterial properties.

Population of moulds in control sample was significantly higher than other variations whereas BKK1 and BAK1 samples were on par with each other. Supplementation of Kariyele or Ambadiyele did not have any impact on mould population. The data pertaining to coliform population of khakhra BKK1 and BAK1 had significantly low population of coliform because betel leaves incorporation inhibited coliform growth compared to control hence, BKK1 found better compared to others. Similar results were observed by Rajamani and Raajeswari (2015) that khakhra witnessed a microbial load of 7 colonies at $10^{-7}$ dilution on the first day while on the third day the number of colonies increased to 10 colonies. There was no fungal and coliform growth even after three days of storage. This could be attributed to very low moisture content of the product. But in the present study, very slight increase in microbial growth i.e. total bacterial count, moulds and coliforms were observed for best accepted betel leaves khakhra (BKK1 and BAK1) as well as control during 60 days of storage period. But microbial load of the developed products were within consumption limit. This could be due to application of heat during preparation of khakhra in addition to its low moisture content.

Moisture content of best accepted khakhra was analysed and presented in Table 6 and Figure 2. The moisture content of the khakhras increased with increasing storage period. For control it was $3.36 \%$ initially and $3.70,3.96,4.30,4.56 \%$ on $15^{\text {th }}, 30^{\text {th }}, 45^{\text {th }}$ and $60^{\text {th }}$ day of storage. For Kariyele khakhra (BKK1) it was $3.43 \%$ initially and 3.61, 4.01, 4.26 and $4.58 \%$ on $15^{\text {th }}, 30^{\text {th }}, 45^{\text {th }}$ and $60^{\text {th }}$ day of storage respectively. Even in case of Ambadiyele khakhra (BAK1) moisture content was increased from $3.83 \%$ initially to $4.39 \%$ on $60^{\text {th }}$ day of storage. Statistically significant difference was observed in 
khakhras during 60 days of storage period. Similarly, Reddy et al., (2014) reported change in moisture content of extruded Ready To Eat (RTE) snacks using corn, black gram, roots and tubers flour blends for the storage period of 2 months. Increase in moisture content of extruded products ranged from 2.14 to $3.29 \mathrm{~g} \%$ at the end of 2 month storage period which was desirable for extruded snacks to maintain crispiness. Authors reported that increase in moisture content may be due to more air spaces in the RTE extruded products on storage.

Sirpatrawn (2008) also reported that moisture content of rice crackers increased during storage period. According to investigator, change in water content directly causes the textural change due to loss of crispness. This may be due to certain factors such as storage temperature, relative humidity and the sorption properties of the product.

It can be concluded from the results that the shelf stable and acceptable value added products can be developed by incorporating dehydrated betel leaves (Kariyele and Ambadiyele) in conventional food items and can enrich the nutritional quality of the products as well as it adds variety to the diet.

\section{Acknowledgement}

I am extremely thankful to the faculty of Department of Food Science and Nutrition, University of Agricultural Sciences, GKVK, Bangalore for their constant encouragement and guidance and kind help throughout my course of investigation.

\section{References}

A.O.A.C., 1980, Official methods of analysis, $13^{\text {th }}$ edition. Association of official agricultural chemists, Washington, D. C. 2004.
Adelowo, F. E., Oladeji, S. O. and Odelade, K. A. 2016. The Spectrophotometric Evaluation of Phosphate in Soil Samples. MAYFEB J. Env. Sci., 1:2029.

Aishwarya, J., Chauhan, E. S., Singh, A. and Tiwari, A. 2016. A Review: Nutraceutical properties of Piper betel (paan). Am. J. of Phytomed. Clini. Ther, 4(2): 028-041.

Chauhan, E. S. and Aishwarya, J. 2016. Proximate and phytochemical scrutiny of Piper betel leaves powder. Int. J. Ayu. Pharm. Chem., 5(2):197-204.

Gopalan, C. Sastri, B. V. R. and Balasubramanian, S. C.1989. Nutritive value of Indian foods. National Institute of Nutrition, ICMR, Hyderabad.

Guha, P. 2006. Betel leaf: the neglected green gold of India. J. Hum. Ecol., 19(2): 8793.

Heau, W. R., Menzel, R. G., Roberts, H. and Freee, M.H. 1965. Methods of soil and plant analysis. Agriculture research service, Department of Agriculture, USA.

Kakade, S. B. and Neeha, V. S. 2014. Dehydration of green leafy vegetable: review. Int. J. Innov. Res. Tech., 1(8): 58- 64.

Kang, H. M. and Saltveit, M. E. 2002. Antioxidant capacity of lettuce leaf tissue increases after wounding. J. Agr. Food Chem., 50: 7536-7541.

Punia, D. and Gupta, M. 2009. Sensory characteristics, nutrient composition and storage studies of value added products for children. Nutri. Food Sci., 39(5): 503- 510.

Rajamani, S. and Raajeswari, P, A. 2015. Development and evaluation of glycaemic index of traditional western Indian food khakhra using low glycaemic ingredients. Int. J. Sci. Res., 5(11): 433- 437. 
Ranganna, S. 2002. Handbook of analysis and quality control for fruit and vegetable products. Tata Mc Graw Hill. Pub. Co. Ltd, New Delhi.

Reddy, K. M., Kuna, A., Devi, L., Krishnaiah, N., Kaur, C. and Nagamalleshwari, Y. 2014. Development of extruded ReadyTo- Eat snacks using corn, black gram, roots and tuber flour blends. J. Food Sci. Technol., 51(9): 1929- 1937.

Singh, L., Yadav, N., Kumar, A. R., Gupta, A. K., Chacko, J., Parvin, K. and Tripathi, V. 2007. Preparation of value added products from dehydrated bathua leaves. (Chenopodium album Linn.). Natural Product Radiance, 6(1): 6- 10.
Sirpatrawan, V. 2008. Shelf life stimulation of packaged rice crackers. J. Food Quality. 32: $224-239$.

Sripradha, S. 2014. Betel leaf - the green gold. J. Pharm. Sci. and Res., 6(1): 3637.

Tauber, H. and Kleiner, I. S. 1935. A method for the quantitative determination of ascorbic acid (vitamin C) content of various plant and animal tissues. J. Bio. Chem., 108: 363-570.

Verma, S. and Bhatnagar, V. 2017. Enhancement of nutritional value of khakhra. Int. J. Food Nutr. Sci., 6(1): 14- 18.

\section{How to cite this article:}

Akshata A. Vernekar, K.G. Vijayalaxmi and Suvarna, V.C. 2018. Development of Value Added Product from Dehydrated Betel Leaves Powder. Int.J.Curr.Microbiol.App.Sci. 7(09): 615-624. doi: https://doi.org/10.20546/ijcmas.2018.709.073 